
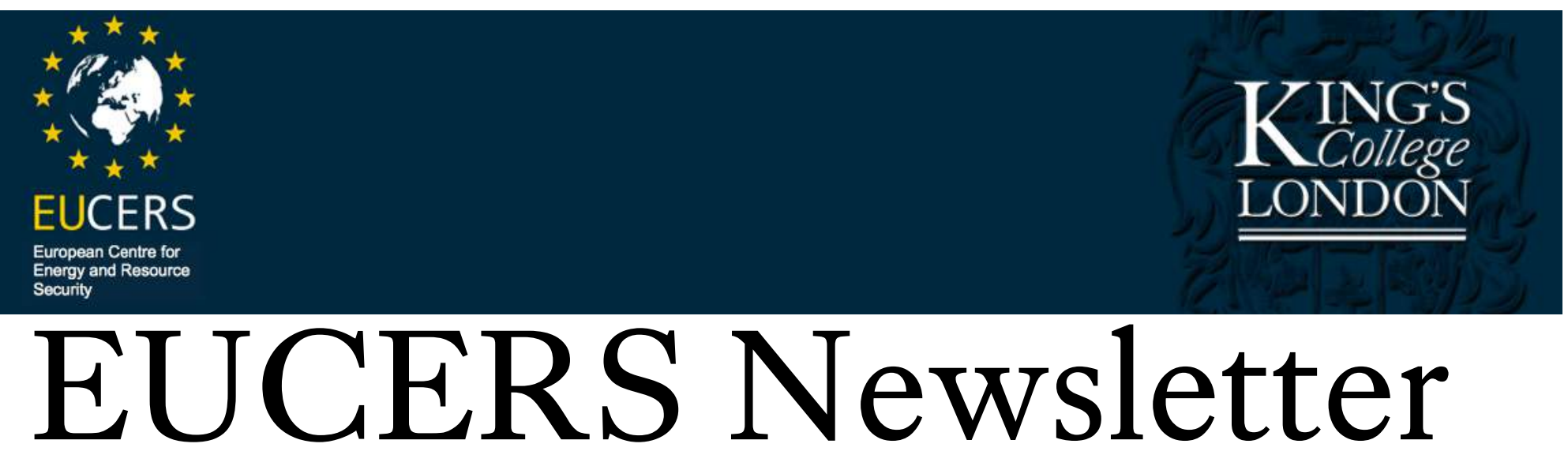

Newsletter of the European Centre for Energy and

Issue 55, June 2016

Resource Security (EUCERS)

\title{
Introduction
}

Dear readers and friends of EUCERS,

In this Month's Edition:

It is my great pleasure to welcome you to the latest edition of the EUCERS newsletter.

In this edition, we present you with two articles. In the first article, Daniel J. Tulloch, a postdoctoral researcher at the University of Oxford Smith School of Enterprise and the Environment, and his co-authors elaborate a new model to assess risk in energy utility returns.

In the second article, Tobias Zumbrägel, a doctoral researcher at the University of Erlangen (Germany), analyses Qatar's ambitions to go green in the near future and asks whether this is likely to succeed or if the country is serious about its green change initiatives.

Furthermore, the newsletter will inform you about the recent activities at EUCERS, including a report on the third EUCERS/KAS/ISD Energy Talk this year, which focused on the future of oil in the Gulf region, and a report about this year's EUCERS Executive Energy Seminar.

Please do keep us informed about your research projects and findings as we look to remain at the forefront of new knowledge and innovative ideas.

Thank you for your interest in EUCERS and for being part of our community.

Yours faithfully,

Thomas Fröhlich

- Introduction

- Newsletter articles

Risk Factors in Energy Utility Returns: An Augmented-Four-Factor Model. By Daniel J. Tulloch, Ivan Diaz-Rainey, and I.M. Premachandra

Is Qatar really going green? By Tobias Zumbrägel

- Activities

EUCERS Executive Energy Seminar 2016

$3^{\text {rd }}$ EUCERS/KAS/ISD Energy Talk "The Gulf Region and the future of oil"

- Announcements

EUCERS/King's Russia Institute Study Presentation: Assessing Nord Stream 2

- EUCERS on the Road

- Publications

- Contact EUCERS

- EUCERS Advisory Board

- Acknowledgements 


\section{Risk Factors in Energy Utility Returns: An Augmented-Four-Factor Model}

\section{By Daniel J. Tulloch, Ivan Diaz-Rainey, and I.M. Premachandra}

A central theme in the finance and energy economics literatures is examining the relationship between risk and return. While a large literature on asset pricing in the context of the oil $\&$ gas industry exists, ${ }^{1}$ asset pricing research on EU energy utilities is largely limited to Oberndorfer (2009) and Koch and Bassen (2013). This is surprising given the importance of the sector and the dramatic changes it has experienced in recent years.

First, and at a more general level, European equity markets have been influenced by market-level macroeconomic events such as the dot-com collapse of 2000, the global financial crisis of 2007 to 2009, and the Eurozone debt crisis of 2010 to 2011. As a result, the valuation of all European stocks has been characterised by large price changes and associated fluctuations in interest rates which reflects changing economic conditions. Second, there have been dramatic changes in the prices of energy-related commodities. By 2008, oil, natural gas, and coal reached record high prices (Oberndorfer, 2009). While oil peaked at about $\$ 140$ per barrel in 2008 , the market price had decreased to around $\$ 30$ per barrel in early-2016. Third, an additional risk factor which is expected to affect all European firms, but especially energy utilities, is the implementation of the EU Emissions Trading Scheme (ETS), introducing carbon price risk. Finally, the sector has also been subject to a myriad of liberalisation and environmental policies which have materially impacted financial returns (Tulloch et al., 2017). Given the importance of EU energy utilities in providing energy to 508 million EU citizens, ${ }^{2}$ and in the desire to transition towards a low-carbon energy system, this paper is principally concerned with the impact of

1 See Manning (1991), Faff and Brailsford (1999), Sadorsky (2001), El-Sharif et al. (2005), Boyer and Filion (2007), Nandha and Faff (2008), Oberndorfer (2009), Elyasiani et al. (2011), Ramos and Veiga (2011).

2 Data extracted from EUROPA: http://europa.eu/abouteu/facts-figures/living/index_en.htm
Daniel J. Tulloch is a postdoctoral research associate at the Smith School of Enterprise and the Environment,

University of Oxford. Daniel completed his PhD in Finance at the University of Otago.

Ivan Diaz-Rainey is a Senior Lecturer in Finance at the University of Otago.

I.M. Premachandra is an Associate Professor in Accountancy and Finance at the University of Otago.

these risk factors and changes on energy utility sector returns.

In this paper we utilise the risk factors from both the finance and energy economics literatures, thereby reintegrating the literatures, to develop a superior asset pricing model in the context of European energy utilities. We develop an Augmented-Four-Factor model (AFFM), which extends the set of variables used to explain returns, including: four stock-market risk factors (market factor, size premium, value premium, and momentum premium), term premium, and commodities previously found to affect energy utility sector returns (oil, coal, natural gas, and carbon).

In developing the AFFM we address four research questions, namely: 1) to what extent do commodity price changes impact the returns in the European energy utility sector, 2) could other risk factors better explain the variation in energy utilities' returns, 3) do the impacts reflect market-wide conditions or the sector-specific relationships between returns and risk premia, and 4) are these risk premia time-varying? Our empirical results are presented in Table 1:

TAble 1: The CAPM, Four-Factor And Augmented ASSET Pricing MOdels

\begin{tabular}{|c|c|c|c|c|}
\hline Coefficient & $\begin{array}{r}\text { (A) } \\
\text { CAPM }\end{array}$ & $\begin{array}{r}\text { (B) } \\
\text { Augmented- } \\
\text { CAPM }\end{array}$ & $\begin{array}{r}(\mathrm{C}) \\
\text { Four-Factor }\end{array}$ & $\begin{array}{r}\text { (D) } \\
\text { AFFM }\end{array}$ \\
\hline$\alpha_{i}$ Intercept & -0.0001 & -0.0001 & -0.0001 & -0.0001 \\
\hline$b_{i}$ Market & $0.7218 * * *$ & $0.7227 * * *$ & $0.6887 * * *$ & $0.6896 * * *$ \\
\hline$s_{i}$ Size & - & - & $-0.1362 * * *$ & $-0.1369 * * *$ \\
\hline$h_{i}$ Value & - & - & $0.2409 * * *$ & $0.2368 * * *$ \\
\hline$m_{i}$ Momentum & - & - & $0.0510 * * *$ & $0.0512 * * *$ \\
\hline$t p_{i}$ Term Premium & - & -0.0017 & - & -0.0117 \\
\hline$o_{i}$ Oil & - & 0.0109 & - & 0.0113 \\
\hline$c_{i}$ Coal & - & $-0.0371 * * *$ & - & $-0.0323 * * *$ \\
\hline$g_{i}$ Gas & - & 0.0020 & - & 0.0019 \\
\hline Adj. $R^{2}$ & 0.6696 & 0.6717 & 0.6863 & 0.6879 \\
\hline$F=$ & $1852.86 * * *$ & $486.99 * * *$ & $520.46 * * *$ & $347.80 * * *$ \\
\hline \multicolumn{5}{|c|}{ 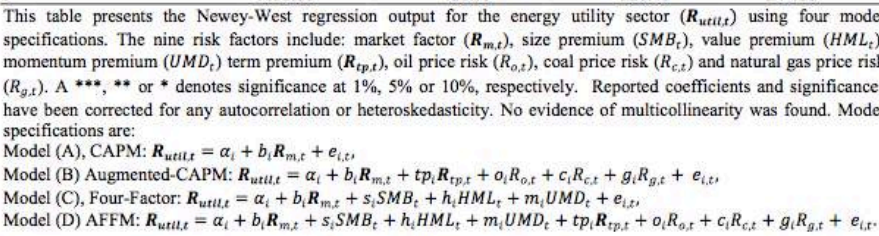 } \\
\hline
\end{tabular}




\section{Research Question 1: The impact of commodities on energy sector returns}

Across all models tested, the European energy utility sector is a defensive investment with a market beta $\left(b \_i\right)$ below unity. The inclusion of term and commodity (oil, coal, and gas) risk factors have little impact in comparison to stock-market risk factors and therefore have a minor role in asset pricing. The results show that coal is the only commodity to have a significant impact on energy sector returns in the long-term. Increasing (decreasing) coal prices decreases (increases) operating profitability; therefore, the impact is expected to be negative for energy-intensive sectors. Despite significance, the magnitude of impact is small - consistent with existing literature (Oberndorfer, 2009; Koch and Bassen, 2013). The lack of oil price risk significance in the utility sector is congruent with Elyasiani et al. (2011) and Koch and Bassen (2013), while Nanda and Faff (2008) and Oberndorfer (2009) find a small, negative impact. Results show that natural gas has no significant impact on the energy utility sector as a whole, congruent with Oberndorfer (2009) and Koch and Bassen (2013). This is expected as energy utilities are expected to hedge against natural gas price fluctuations in the long term.

Research Question 2: The impact of stock-market risk factors on energy sector returns

Fama and French (1993) argue that the market factor is a 'hodgepodge' of multiple stock-market risk factors, which must be isolated. While market premium continues to be the most significant risk factor, size, value and momentum premia are also major determinants of returns in the energy sector. The negative $S M B$ coefficient shows that utilities' returns behave like big European stocks, indicating that the largest utilities dominate sector returns. The positive $H M L$ coefficient shows that energy utilities behave like distressed European stocks; congruent with the perceived negative impact of liberalisation in the energy sector. The inclusion of value premium reduced the magnitude of the coal coefficient. ${ }^{3}$ This impact shows that coal risk proxies for some element of firm distress for utilities. The positive $U M D$ coefficient shows the sector returns behave like upper momentum European stocks, indicating excess returns and/or oligopoly power.
Research Question 3: Market-wide conditions or the sector-specific relationships?

As industries are not homogeneous, there is likely to be negative price sensitivities in industries with a relatively high proportion of their costs devoted to commoditybased inputs (Faff and Brailsford, 1999). Our multivariate regression results ${ }^{4}$ show that each sector has distinct sensitivities to various risk factors. Importantly, the results for the energy utility sector were different to those of the Oil \& Gas sector. The results suggest that the risk premium for the energy utility sector reflect a sectorspecific relationship, rather than a market-wide concern across the economy, and is motivation for further investigation into asset pricing in energy sector in isolation.

Research Question 4: Are these risk premia timevarying?

We conduct conditional AFFM regressions on a year-byyear basis between 1996 and 2013 to examine parameter stability. The inter-temporal results are shown in Figure 1. The market beta shows the energy utility sector is becoming increasingly exposed to systematic risk and losing its role as a defensive investment asset. The market dominance of big utilities has become more significant through time, despite liberalisation's attempts to create a level playing field and reduce market dominance and predatory behaviour. The removal of national barriers allowed big energy utilities to rapidly expand into previously isolated international markets. The energy utility sector typically behaves like distressed (high bookto-market) European stocks. The impacts mostly occur one to two years after major packages of liberalisation. Finally, the sector mostly behaves like upper momentum stocks through time. Downwards momentum is observed following major packages of liberalisation. We conclude the momentum coefficient captures the shift when past winners (losers) become losers (winners).
3 In other sectors, the value premium also reduced the significance of estimated coefficients.

\footnotetext{
${ }^{4}$ Results are available in the full paper.
} 
Figure 1: INTER-TEMPORAL AFFM COEFFICIENTS AND 95\% CONFIDENCE INTERVALS

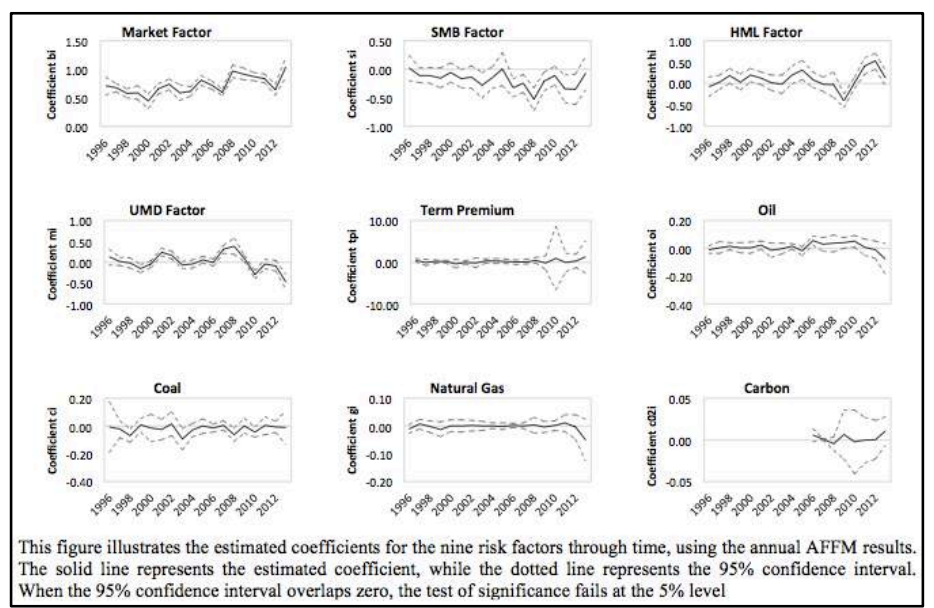

The results also show varying commodity risk exposure over time. Coal was the most significant commodity, followed by oil, term premium, carbon and gas - where both carbon and gas showed no significance through time. The significant coal coefficients typically occur in years with large price spikes or volatile coal returns. It is possible that the coal price sensitivity represents the impact of unexpected fluctuations in coal price, where a sudden decrease (increase) in coal price increases (decreases) the dark spread for electricity generation and increases (decreases) firm value.

\section{Conclusions}

Methodologically, the improved asset pricing model helps establish a more accurate equilibrium asset pricing function, which can be used in a variety of applications which require estimates of stock returns, and has implications for modelling average returns at the sectorlevel. Qualitatively, this paper demonstrates that sectors are not homogenous and have differential impacts to stock market, term premium and commodity risk factors. Further, these risk exposures vary across time. An understanding of the impact of economic factors on equity returns facilitates greater understanding of risk premia and management within the sector. The detection of coal price risk shows that energy utilities have not, or are unable to, fully realised the benefits of coal risk management, failing to hedge against coal price fluctuations. Further, the results make a major contribution to energy policy by being the first to empirically show that the European energy utility sector is becoming increasingly exposed to systematic risk, the size premium has increased over time despite regulatory changes designed to counteract the dominance of big energy utilities, and the energy sector becomes extremely distressed following the third liberalisation package.

\section{References}

Boyer, M.M., Filion, D., 2007. Common and fundamental factors in stock returns of Canadian oil and gas companies. Energy Econ. 29, 428-453. doi:http://dx.doi.org/10.1016/j.eneco.2005.12.003

El-Sharif, I., Brown, D., Burton, B., Nixon, B., Russell, A., 2005. Evidence on the nature and extent of the relationship between oil prices and equity values in the UK. Energy Econ. 27, 819-830. doi:http://dx.doi.org/10.1016/j.eneco.2005.09.002 Elyasiani, E., Mansur, I., Odusami, B., 2011. Oil price shocks and industry stock returns. Energy Econ. 33, 966974. doi:http://dx.doi.org/10.1016/j.eneco.2011.03.013 Faff, R.W., Brailsford, T.J., 1999. Oil price risk and the Australian stock market. J. Energy Financ. Dev. 4, 69-87. doi:http://dx.doi.org/10.1016/S1085-7443(99)00005-8 Fama, E.F., French, K.R., 1993. Common risk factors in the returns on stocks and bonds. J. financ. econ. 33, 3-56. Koch, N., Bassen, A., 2013. Valuing the carbon exposure of European utilities. The role of fuel mix, permit allocation and replacement investments. Energy Econ. 36, 431-443.

doi:http://dx.doi.org/10.1016/j.eneco.2012.09.019

Manning, N., 1991. The UK oil industry: some inferences from the efficient market hypothesis. Scott. J. Polit. Econ. 38, 324-334. doi:10.1111/j.1467-9485.1991.tb00321.x Nandha, M., Faff, R., 2008. Does oil move equity prices? A global view. Energy Econ. 30, 986-997. doi:http://dx.doi.org/10.1016/j.eneco.2007.09.003 Oberndorfer, U., 2009. Energy prices, volatility, and the stock market: Evidence from the Eurozone. Energy Policy 37, 5787-5795. doi:http://dx.doi.org/10.1016/j.enpol.2009.08.043

Ramos, S.B., Veiga, H., 2011. Risk factors in oil and gas industry returns: International evidence. Energy Econ. 33 ,

$525-542$.

doi:http://dx.doi.org/10.1016/j.eneco.2010.10.005

Sadorsky, P., 2001. Risk factors in stock returns of Canadian oil and gas companies. Energy Econ. 23, 17-28. doi:http://dx.doi.org/10.1016/S0140-9883(00)00072-4 Tulloch, D.J., Diaz-Rainey, I., Premachandra, I.M., 2017. The Impact of Liberalization and Environmental 
Policy on the Financial Returns of European Energy Utilities. Energy J. 38, 77-106. doi:http://dx.doi.org/10.5547/01956574.38.2.dtul

N.B.: This article is an abbreviated version of the full research article, which is currently under review for journal publication.

\section{Is Qatar really going green?}

\section{By Tobias Zumbrägel}

In the last years, the tiny Qatari emirate has been at the forefront to enact its role as a climate power advocate. In this sense, Qatar General Electricity and Water Corporation, Kahramaa, has started to deploy a project in 2011 to secure future demands on water as a first step. The project costs US\$2.5 billion and comprises two desalination plants and five water reservoirs. ${ }^{5}$ The campaign will be completed by 2017, but it has already saved nearly 1.8 million tons of greenhouse gas (GHG) emissions and reduces gas waste by 43.000 million cubic foot by the end of December 2014. ${ }^{6}$ As one of the most important drivers towards sustainable development Kahramaa has also announced recently that it will "enact a landmark legislation against wastage of energy and water resources".

\section{Changing patterns...}

The project can be translated as 'best effective use' or 'rationalization' (Tarsheed) and aims at launching different initiatives for a better societal encouragement of energy efficiency. Although its status is still under implementation, it is targeted to reduce electricity consumption by $20 \%$ and water by $35 \%$ until the end of

\footnotetext{
${ }^{5}$ Luomi, M. (2012b): The Gulf Monarchies and Climate Change. Abu Dhabi and Qatar in an Era of Natural Unsustainability, London: C. Hurst \& Co (Publishers) Ltd., p. 176.

${ }^{6}$ Arab Sustainability Association (2015): Qatar's Roadmap to Achieve Sustainability; Retrieved June 6, 2016 from http://www.ifpinfo.com/asa/asa-news.php?news_id=6327

${ }^{7}$ Gulf Times (2015): Qatar Takes a Major Initiative to Conserve Water and Electricity; Retrieved June 5, 2016 from http://www.gulf-

times.com/Mobile/Opinion/189/details/428129/Qatar-takes-amajor-initiative-to-conserve-water-and-electricity
}

Tobias Zumbrägel is a doctoral researcher at the University of Erlangen. His research focuses on "New Sources of Legitimacy: the Promotion of Climate Protection in Arab Gulf Monarchies". With a B.A. in Islamic Studies and History from the University of Cologne and a double M.A. in "Comparative \& Middle East Politics and Society" from the University of Tübingen and the American University Cairo, Tobias is a recipient of a Zeit-Foundation fellowship.

2017. ${ }^{8}$ Similar, many solar energy sources have been established to fulfil the emirate's ambitious aim of provide $20 \%$ of the country's total energy from renewable sources by $2024 .{ }^{9}$ Beside some small solar plants, certainly the 'flagship' is the Solar Smart-Grid Project, which is located in Education city. ${ }^{10}$ Established in 2012, the Qatar Foundation has announced lately that the solar photovoltaic systems will be capable of producing $1.6800 \mathrm{MW}$ by 2020 , i.e. approximately $15 \%$ of the total energy consumption. ${ }^{11}$

Furthermore, Qatar is involved in several mitigation strategies in order to reduce its overall GHG emissions. The country's most well-known exemplary clean development project is the al-Shaheen Oilfield Gas Recovery and Utilisation Project in cooperation with Maersk Oil Denmark. It aims at capturing the associated gas that previously was flared. In so doing, it saves 2.49 million tonnes of $\mathrm{CO}_{2}$ per year. The former Minister of Environment introduced this project in 2012 by emphasizing that it is "the first of its kind in the Middle East and a clear evidence of the importance of the environment in Qatar". ${ }^{12}$ Akin, the development of the al-Karkara oil field was completed by 2012 that is

\footnotetext{
8 Al-Sharq bi-Waba (2015): 'Kahramaa' tatalaqqa musabaqa afdalla mubadira fi al-ta'qqa al-mutajadida; Retrieved June 2, 2016 from http://www.alsharq.com/news/details/325340\#.VaPsN_mDRsk

${ }^{9}$ Yeo, S. (2014): Qatar targets solar revolution, but pace remains slow, in: Responding to Climate Change (RTCC); Retrieved June 4, 2016 from http://www.rtcc.org/2014/07/03/qatar-targetssolar-revolution-but-pace-remains-

slow/\#sthash.hhETVw3w.dpuf

${ }^{10}$ Solar GCC Alliance (2015): Solar Update Qatar; Retrieved June 4, 2016 from http://www.solargcc.com/qatar-solar/

11 Qatar Foundation (QF) (2014): Qatar's New Energy Horizons; Retrieved June 6, 2016 from http://www.qf.org.qa/content/thefoundation/issue-68/qatars-new-energy-horizons

12 The Peninsula (2012): Seize opportunity to reach accord: Minister; Retrieved June 6, 2016 from http://thepeninsulaqatar.com/news/qatar/217027/seizeopportunity-to-reach-accord-minister.
} 
supposed to be the first field to have zero gas flaring. Another domestic undertaking worth mentioning is the Jetty Boil-off Gas Recovery (JBOG) project in the city of Ras Laffan. This cooperation project, which is under the umbrella of local companies like Qatar Petroleum, Qatargas, and RasGas, aims at reducing $90 \%$ current flaring. ${ }^{13}$ Additionally, better transport systems are planned, which are expected to be completed before the arrival of the millions of guests for the soccer world cup in 2022. Hence, Qatar's rail manager director highlighted at a summit lately that the future Doha Metro will reduce annual $\mathrm{CO}_{2}$ emissions of 258,000 tonnes. ${ }^{14}$ Apart from all mentioned examples, it is predominantly the announcement of building eight (previously twelve) stadia with solar panels and to host the world's first carbon-neutral soccer world championships that has gained a huge international recognition of Qatar's new environmental role. ${ }^{15}$

\section{...and stagnancy}

Does all this mean that Qatar has undergone a radical profound change in environmentalism? This seems to be highly doubtful! Instead, it is argued here that those examples can primarily be perceived as brand showcasing and 'greenwashing' methods that have very little to do with a substantial and authentic commitment to a sustainable development. In other words, those environmental targets and actions are aimed in significant matter at achieving non-environmental goals; particularly reputational and socioeconomic benefits. First, it is baffling that there has almost none environmental concern in Qatar before autumn 2011. Quite the contrary, since the mid-2000s international environmental rankings and indexes had exposed the unsustainable lifestyle and modernisation course based

\footnotetext{
${ }^{13}$ Alagos, P. (2015): JBOG Project to Cut LNG Carbon Emissions in Qatar, in: Gulf Times; Retrieved June 6, 2016 from http://www.gulf-times.com/eco.-

bus.\%20news/256/details/436980/jbog-project-to-cut-Ingcarbon-emissions-in-qatar.

${ }^{14}$ Alagos, P. (2015): 'Doha Metro will help cut emissions', in: Gulf Times; Retrieved June 5, 2016 from http://www.gulftimes.com/qatar/178/details/434830/\%E2\%80\%98doha-metrowill-help-cut-emissions\%E2\%80\%99.

${ }^{15}$ Laylin, T. (2014b): Qatar Axes Four of 12 Solar-powered World Cup 2022 Stadiums, in: Green Prophet. Sustainable News for the Middle East; Retrieved June 3, 2016 from http://www.greenprophet.com/2014/04/qatar-axes-four-of-12solar-powered-world-cup-2022-stadiums/.
}

on hydrocarbons producing high emissions of climatedamaging gases. ${ }^{16}$ The same can be said for Qatar's behaviour within the global climate regime, which was rather laggard as the emirate continuously referred to its status as a developing (i.e. non-annex) country. Only when the country declared to be the host of the upcoming climate conference in 2012, it had to come up with an authentic climate policy to present itself as a reliable host. Thus, it is doubtful that it was a coincidence that Qatar initiated a commission to develop a national and international agenda for combating climate change and presented its first solar energy projects shortly after winning the bid for hosting the $18^{\text {th }}$ Conference of the Parties (COP) of the United Nations Framework Convention for Climate Change (UNFCCC).

Second and related to the above-stated, in Qatar exists a close interlinkage of political interests with the private hydrocarbon business sector. Thus, one can find steadily growing export volumes of particularly liquid natural gas (LNG), many greenwashing initiatives by the biggest oil- and gas companies, and the fact that main research is concerned with mitigation strategies like Carbon Dioxide Capture and Storage (CSS) that help to extend the era of hydrocarbon energy sources. This is important because Qatar is considered as a typical example of a rentier state. Hence, it wants to ensure its state capitalism system in a long-term by claiming that "growth in industrial capital can offset losses in natural resources and ecosystem services as long as welfare levels are maintained". ${ }^{17}$ Moreover, the high involvement in CCS research can be explained by the fact that Qatar would receive financial compensation from Annex I states for every implemented project under the UNFCCG frameworks of either the clean development mechanisms (CDM) or nationally appropriate mitigation actions (NAMAs). ${ }^{18}$ Furthermore, securing domestic energy by renewable energy resources would provide

\footnotetext{
${ }^{16}$ Luomi 2012b, p. 70

17 Luomi, M. (2012a): Qatar's Natural Sustainability: Plans, Perceptions, and Pitfalls. Occasional Paper Center for International and Regional Studies, Georgetown University School of Foreign Service in Qatar, No. 11, p. 5; Ulrichsen, K. (2014a): Qatar and the Arab Spring, London: Hurst \& Company.

18 Luomi 2012b, pp. 43; Caravani, A. et. al. (2012): Climate Finance for the Middle East and North Africa: Confronting the Challenges of Climate Change. Heinrich Böll Foundation Climate Finance Policy Brief.
} 
the possibility to export energy to other GCC states (what Qatar is already doing), on the one hand, but it would also ensure additional LNG to the exporting sector in general, on the other hand. As has been seen, especially the expansion of the LNG exports is crucial for the country's socioeconomic stability.

\section{Qatar's green turn revisited}

It has been shown that Qatar's recent green turn is rather cosmetic that serves primarily state interests of reputation and socioeconomic stability. However, while this does not mean that it is completely ineffective to tackle environmental problems, simultaneously it does not mean that implementing a climate-related policy means the end of the era of fossil fuels or rentier state structures. Hence, it is doubtful that one can expect an authentic pledge in the near future such as cutting subsidies or introducing regulations like an ecological tax reform or feed-in tariffs as in Germany (Einspeisevergütung), also a carbon price or market seem still more than unlikely. ${ }^{19}$ This is mostly due to the fact that it would threaten the allocative character of the authoritarian state which is a main pillar of stability.

\section{DISCLAIMER}

The views expressed in this Neresletter are strictly those of the authors and do not necessarily reflect those of the European Centre for Energy and Resource Security (EUCERS), its affiliates or King's College London.

\footnotetext{
${ }^{19}$ Reiche, D. (2010): Energy Policies of Gulf Cooperation Council (GCC) Countries - Possibilities and Limitations of Ecological Modernization in Rentier states, in: Energy Policy, Vol. 38 (5), S. 2395-2403; Meltzer, J. et. al. (2014): Low-Carbon Energy Transitions in Qatar and the Gulf Cooperation Council Region. Global Economy and Development at Brookings Working Paper, p. 25; Luomi, M. / Michaelowa, A. (2012): From Climate Antagonists to Low-Carbon Protagonists? The Changing Role of the Gulf OPEC States in the UNFCCC. Fridtjof Nansen Institute (FNI) (=FNI Climate Policy Perspectives 6), p. 6; Luomi, M. (2014): Mainstreaming Climate Policy in the Gulf Cooperation Council States. Oxford Institute for Energy Studies (OIES) Paper: MEP 7, p. 40.
} 


\section{ACTIVITIES}

\section{EUCERS Executive Energy Seminar 2016}

\section{Seminar Report}

The European Centre for Energy and Resource Security (EUCERS) at King's College London, in cooperation with the King's Summer School, organised the 5th EUCERS Executive Energy Seminar (EEES). It took place from the 23rd to $27^{\text {th }}$ of May and was chaired by Dr Frank Umbach, Associate Director at EUCERS. As in previous years, the EEES focused on the "Changes and Challenges in International Energy Markets"; highcalibre, energy experts, academics, energy executives and representatives from private and public institutions, gathered for a heated and thorough debate on the newest trends and forthcoming challenges to global energy developments.

A dynamic group of energy experts, with different expertise and backgrounds, benefited from the insightful contributions of the invited speakers who covered a variety of topical energy issues. The sessions were interactive, followed by Q\&As, providing the opportunity for the participants to share their opinions and experience with the speakers. The range of session topics varied from traditional issues, such as the future of the international hydrocarbons markets and implications for the EU and the rise of renewables through the prism of the German 'Energiewende', to more prevailing ones, like the digitalisation of the global energy industry and the political communication of energy projects. A regional focus was set on the Iraqi oil sector and the Seminar's participants had the opportunity to attend the Iraq Petroleum 2016 conference.

Dr Frank Umbach, EUCERS Associate Director, gave participants a comprehensive overview of the changes and challenges in international energy markets. He outlined the issues of fossil fuel divestment; the new dimensions of energy security, and the supply vulnerabilities associated with final consumption and critical energy infrastructures. Other experts contributed to Frank's overview. Mohammed Shakeel, Political Analyst in Global Strategy and Business Development at Statoil, offered specific examples of the security threats in oil $\mathscr{E}$ gas industry. Peter Mather, Group Regional Vice President at BP in
Europe presented BP's forecasts of the changes and challenges for global oil and gas markets.

In addition to the Iraq Petroleum Conference EES participants also had the opportunity to attend the workshop "The Gulf Region and the Future of Oil'. This was the second in a series of four workshops, organised by EUCERS together with the Institute for Strategic Dialogue (ISD) and the Konrad Adenauer Foundation (KAS), to discuss this focal energy issue with policy makers, academics, media representatives, international and industry experts,. Ben Lando and Jared Levy, from the Iraq Oil Report, delivered a vivid presentation on Iraq's oil sector trajectories, providing significant regional facts and figures.

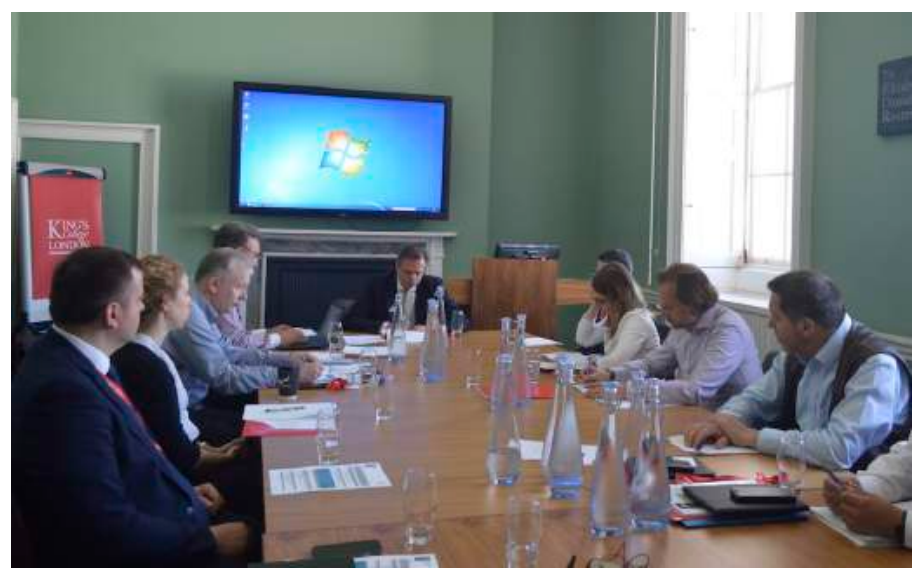

The EU's current and future energy challenges were core of the EEES' agenda. Professor Dr Friedbert Pflüger, director of EUCERS, delivered a thorough analysis on the Nordstream 2 pipeline. Further, Professor Andreas Golthau highlighted the implications of Nordstream 2 for future of EU - Russian energy partnership while, Dr Anita Orban and Andrew Walker, from Cheniere Energy, illustrated the influence of LNG in European and global gas markets. Aura Sabadus, editor in Turkish Energy Hub Daily ICIS, also shed light on the opportunities and barriers Turkey faces in becoming an energy hub for Europe. Michael Feist, the former CEO Enercity discussed the issues of lesson learnt from the German "Energiewende", giving the opportunity for a heated debate on clean energy transition, climate change mitigation, and renewables expansion in EU energy policy. Matthias Dürr, Head of Office RWE AG in Brussels, delivered a presentation about the vision of Energy Union and its implications for the European energy markets. 


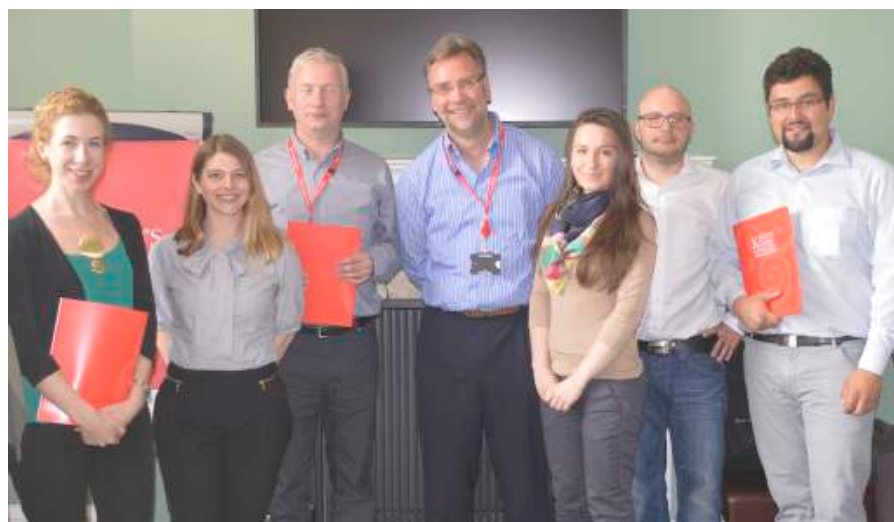

The EEES week was concluded by an exciting presentation from Christophe Mielke and Thomas Eymond Laritaz from APCO Worldwide. They discussed the political communication of energy policies and projects, capturing the audience's attention on how decisive the communication could be for the public support or the financing of an energy project. This issue was further elaborated on by Rob Tims, former Managing Director of Oil and Gas at Standard Chartered Bank. On the final day of the EEES, the participants shared their opinions about the seminar's content and structure in a feedback session to improve future seminars. A successful week was celebrated at the closing ceremony in which certificates were handed out.

The EEES's social program included a visit to the London Eye, and social dinners where the participants had the opportunity to continue discussions on energy security in a more relaxed environment. There was also a session dedicated to group work activity. The participants worked in two groups, presenting their views and arguments on a case study of the divestment movement. All reacted very positively to this group activity expressing satisfaction with the way the activity encouraged them to digest and used information from the presentations.

The EUCERS team was delighted to welcome all participants and distinguished speakers to this year's executive energy seminar and are looking forward to organising the next executive energy seminar in 2017. We would like to thank the Chairman of the programme Dr Frank Umbach, the presenters, participants and Carola Gegenbauer, organiser of the EEES, for making this seminar a valuable experience for all.
For more information please email Carola on carola.gegenbauer@kcl.ac.uk.

\section{Dr.Maria Kottari, EUCERS Research Associate}

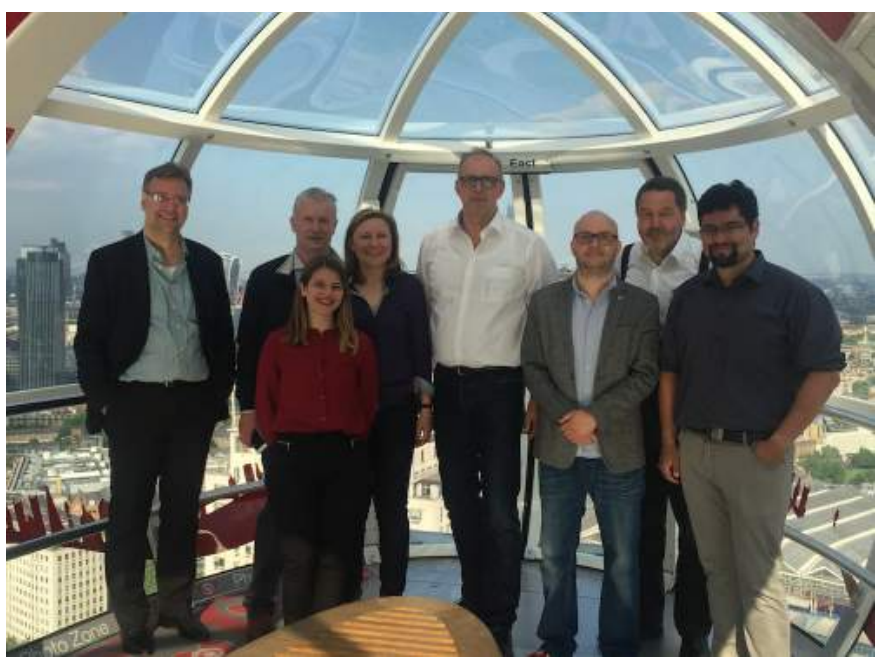




\section{EUCERS/KAS/ISD Energy Talk 3/2016}

\section{The Gulf Region and the Future of Oil}

\section{Conference Report}

The third workshop of the 2016 Energy Talks by the European Centre for Energy and Resource Security (EUCERS), the Konrad Adenauer Foundation (KAS), and the Institute for Strategic Dialogue (ISD) took place on Monday $23^{\text {rd }}$ of May. Hosted in the River Room, in the main King's College London building, we had the opportunity to listen to a very rich panel. This included Mr Hans-Hartwig Blomeier, Director of KAS' London office; Dr Friedbert Pflüger, EUCERS Director; Geir Westgaard, Statoil's VP of Political Analysis, Global Strategy and Business Development; Julian Lee, Strategist at Bloomberg; Dr Carole Nakhle, Director at Crystol Energy; Dr Frank Umbach, Research Director at EUCERS, Stefan Haid, Principal of Civil Economics, Energy and Infrastructure at Roland Berger $\mathrm{GmbH}$ and EU-Iraq Energy Centre project responsible; and Kalina Damianova, Research Associate at EUCERS. Following, an insight into the discussion. ${ }^{1}$

Mr Hans-Hartwig Blomeier. The workshop was opened by $\mathrm{Mr}$ Blomeier, who welcomed the audience. $\mathrm{Mr}$ Blomeier briefly mentioned that this event is part of a series of discussions about the topic of the future of oil. $\mathrm{He}$ noted how just a month ago we gathered to discuss the future of oil prices, and that we were in Edinburgh in January discussing the future of oil in the North Sea. Given that the conference included several speakers, $\mathrm{Mr}$ Blomeier wanted to be brief with his introduction. Thus, he thanked EUCERS and ISD for their on-going cooperation and then proceeded to give the room to the speakers.

Dr Friedbert Pflüger. In his introductory remarks Dr Pflüger begun by thanking the partners KAS and the ISD for the continuous cooperation. He then highlighted the importance of oil prices for war studies and international stability. Dr Pflüger also noted that it is important to bear in mind that whilst most producers have discussed diversification for several years, there has been little progress in this regard. Even the rich producing countries, such as Saudi Arabia, are finding it hard to meet their budgetary needs. Dr Pflüger also mentioned that another issue of concern is that OPEC represents the region with most reserves in the world, but not able to balance markets, as shown by the failure in Doha. Furthermore, he added that there are many open questions, such as the role of Iran in the future. To close his introduction, Dr Pflüger brought attention to the rapidly changing nature of markets, as only some years ago we were talking about the challenges of peak oil.

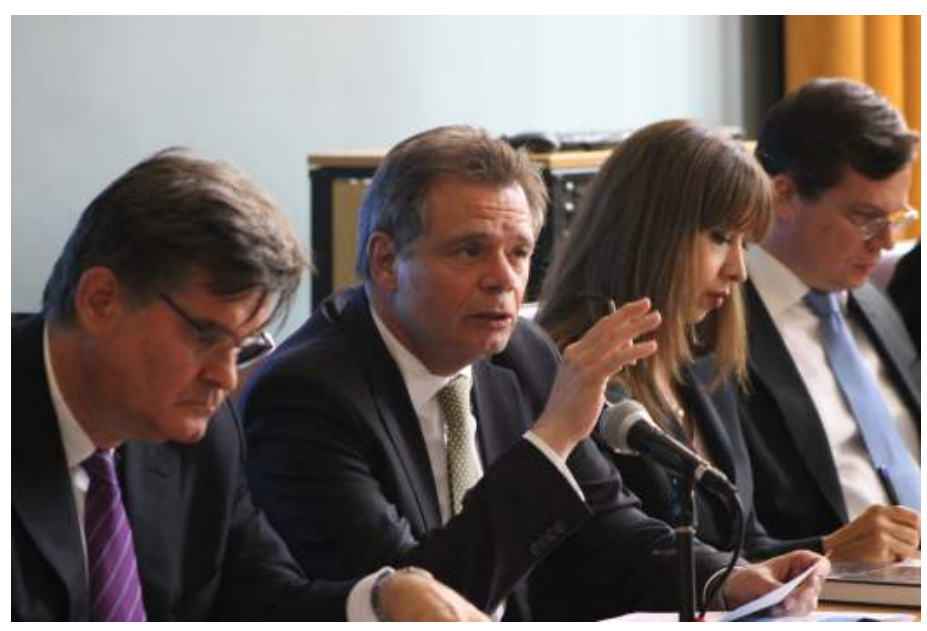

Geir Westgaard. Mr Westgaard's participation begun by noting that the Gulf's situation is so complex that it is impossible to summarise everything in a short talk. As such a focus on Saudi Arabia can help identifying the most significant trends. He begun by noting that the three main factors behind's OPEC 2014 decision to not cut production, all of them directly related to Saudi Arabia. These were: the determination to recapture market share, a desire to challenge Iran's comeback, a desire to push production to avoid being left with stranded assets. $\mathrm{Mr}$ Westgaard then continued the discussion by elaborating on this idea before he moved onto the policy measures that have been necessary to manage low oil prices, such as the use of foreign reserves, budget considerations, lending from international banks, and even the introduction of VAT. However, as noted by Mr Westgaard, it is clear that fiscal adjustments will not suffice, as there is a need for a deeper structural reform. Mr Westgaard then considered the likelihood that the Saudi Arabia's 'Vision 2030' (also known as McKinsey Plan) succeeds at delivering said reform.

1 Due to the high number of speakers the insights are not comprehensive, focusing instead on a general reflection of the discussion. 


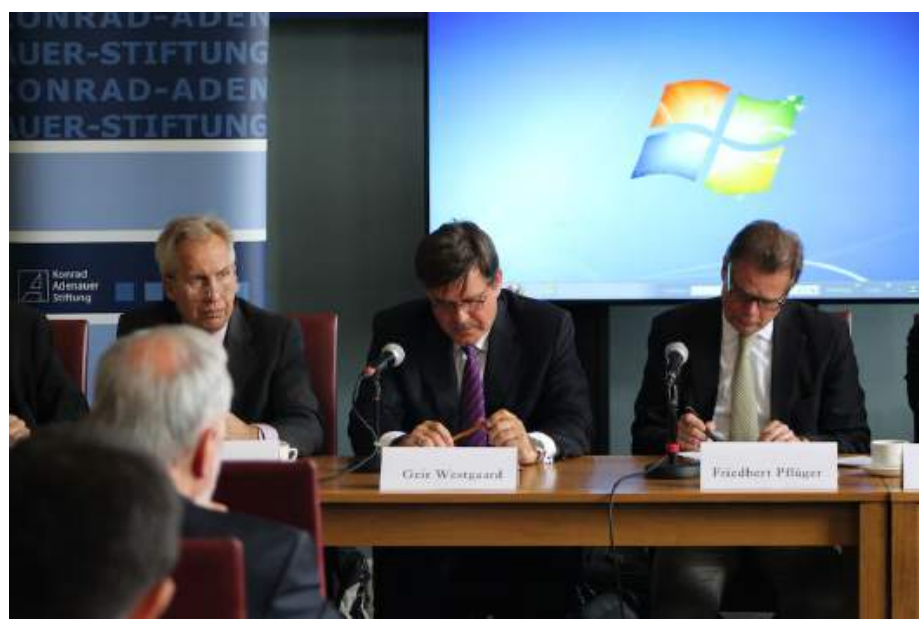

Julian Lee. Mr Lee started by noting that in his view the decision to not cut production in 2014 was a Saudi policy, rather than OPEC's. Mr Lee agreed to what was noted by Mr Westgaard. He added that the experience of trying, and failing, to defend prices in the late $70 \mathrm{~s}$ and $80 \mathrm{~s}$ also cemented the determination to not try this time. Mr Lee's intervention then moved into considering the results that the 2014 decision to not cut oil production has brought to Saudi Arabia, noting that the decision brought about both benefits and costs. Having done these considerations, there might be a problem at the heart of how we look at it, as we tend to get predictions about markets wrong. $\mathrm{He}$ noted, for example, the belief that prices could only go back up in times of high oil prices, and the idea that US shale would exit the market promptly due to low prices which is yet to happen. Nowadays we believe that when prices come back up, new production will rapidly hit the market. However, Mr Lee's final segment looked at different reasons why this may not be the case, including the not-easily-recoverable loss of human capital, the impact to credit worthiness of existing companies, and a problem of diminishing spare production capacity around the globe due to different geopolitical issues. Mr Lee closed his talk by noting that these, and other considerations done in the talk, are ideas for further thinking.

Dr Carole Nakhle. Dr Nakhle begun by stating that there are two perspectives to the discussion, the short and the long term. Speaking of the short term, Dr Nakhle noted that OPEC's, and in particular Saudi Arabia's, strategy since 2014 has two main objectives: to stop US from gaining market share, which was achieved; and to stop own loss of market share, which has not been achieved. Dr Nakhle then noted that it is important to consider the question of what the Saudi government really believes about whether low oil prices are good for the economy given the extensive reform agenda that they have. After this, Dr Nakhle moved onto the topic of OPEC's relevance. She noted, for example, that Doha is not necessarily a failure because OPEC's history shows that sometimes there is no need for formal agreements for results to emerge. Continuing with her view of short and long-term perspectives $\mathrm{Dr}$ Nakhle then examined different challenges that are relevant for the future of oil in the region. She noted, for example, the short-term relation between oil companies and governments and oil prices, financing difficulties to be encountered in the near future, and the long-term challenge represented by climate change. Dr Nakhle's intervention finished by noting that a concerning fact is that there is no comprehensive energy policy in the region, as there are many good intentions but a big challenge of implementation.

Frank Umbach. Looking at the bigger picture, Dr Umbach's argument flowed alongside a number of key considerations. He reminded the audience that already at the outbreak of the last Gulf war in 2001, the US was already less dependent on oil supplies from the Gulf region compared with Europe and in particular East Asia. Meanwhile the US oil imports from the Gulf have further declined (to less than 10\%), whereas the import dependence of Europe (around 30\%) and Asia (70\%) have remained, which have increased US demands for larger burden-sharing (i.e. security commitments) by Europe and Asia. Looking ahead, example, Dr Umbach noted that the entire region is at a crossroads, derived not from any-one element alone but the combination of various trends - which creates a dynamic of its own and which appears to be underestimated in Europe and the U.S. Dr Umbach also brought up many conflicts faced by the region, such as the increasing geo-economic and geopolitical rivalry between Saudi Arabia and Iran (leading even to proxy wars in Yemen and Syria), as well as the fact that new generations are coming to power, which is accompanied by new personal ambitions. Dr Umbach considered that these are developments that we must anticipate. After this Dr Umbach turned to the difficulties of anticipating the future. He noted, for example, that Saudis miscalculated the resilience of US shale. That said, he also noted that technologies are impossible to bankrupt and as such even if the price war is placing some companies under pressure, the technology remains there and can rapidly increase the U.S. 
production when the oil cycle turns to more than US $\$ 50$ 60 per barrel. Dr Umbach then moved to the role that China might have to the future of oil. China's oil demand and storage capacity combined with the present economic transformation away from heavy industries may significantly reshape the global oil demand. Also on the topic of storage, he noted that the Gulf's storage capacity could become a source of major changes as new leaders are less interested in favouring US and European interests with it. To end his intervention, Dr Umbach turned into considerations about Saudi Arabia's spare production capacity, which has been already lower than the IEA has recommended for some years. Given its overall geopolitical importance, he noted that it has been referred to by US experts as the "nuclear weapon in the oil industry". He noted that this factor might also bring about significant changes to the future supply and demand balance.

Stefan Haid. Mr Haid focused his presentation on Iraq. $\mathrm{He}$ started by remarking that the low oil price has definitely hit Iraq but that the ISIS insurgency has also been a major challenge. Coupled with a collapse in public services, public protests, deficits, the tumbling infrastructure, the investment required for the oil industry, the situation faced by the government is one of extreme pressure. In addition, he noted that the Kurdistan region is a further source of challenges for the government because, whilst there has been some cooperation to counter ISIS, many conflicts are still to be resolved. Despite of all this, Mr Haid noted that there are some sources of hope. In his view, Prime Minister Mr Al-Abadi has been able to keep the government together despite of the intense pressure. Similarly, he noted, the military has made a comeback after initially ceding ground to ISIS. Another point that needs consideration, noted by $\mathrm{Mr}$ Haid, is the stabilizing role that Iran has played. Finally, $\mathrm{Mr}$ Haid stated that revenues are still coming despite of the low oil prices. To summarize; the big challenge is the question of 'how to stabilize Iraq'. In Mr Haid's regard, the challenge lies in successfully implementing reforms. For this purpose initiatives like the EU-Iraq energy centre can be vehicles to enhance cooperation with those in Iraq that are willing to implement reforms. An important aspect of this effort, noted $\mathrm{Mr}$ Haid, is to increase capacity development and further incentivise research. To close, Mr Haid made emphasis on the fact that if Iraq collapses the whole region will face an even bigger challenge.
Kalina Damianova. Ms Damianova focused on the role that Iran may play to the region and the future of oil globally. According to Ms Damianova, Iran's nearly presanction levels of increased oil production and export showed that Iran was following a long-term strategy, where the current low prices mattered little compared to the perspectives of its re-gained market share and reestablished international position. Additionally, she suggested that extracting as much oil as possible from the ground could be a "now or never" approach, as the uncertain future of the global oil markets significantly increased competition for market share regionally and globally. After this Ms Damianova suggested three shortterm scenarios for Iran's production increase: A low case that envisaged almost no change or little increase in oil production; a very optimistic scenario of 4 to 4.2 $\mathrm{MMbbl} / \mathrm{d}$ according to the statements done by Iran's officials, and a third scenario suggesting a production increase up to $3.7 \mathrm{MMbbl} / \mathrm{d}$ until the 1 st quarter of 2017. Ms Damianova concluded that beyond 3.7 MMbbl/d Iran would need significant investments to continue increasing production.

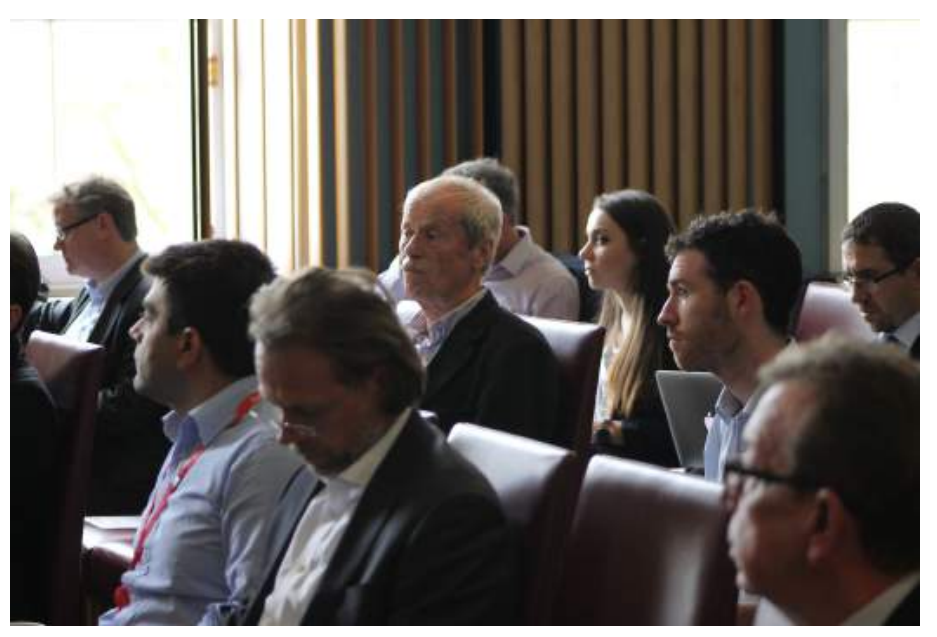

Questions $\mathscr{E}$ Answers (QËA)

A Q\&A followed the keynotes. Following the format of previous EUCERS/KAS/ISD Energy Talks, QÆA's will be left out of this summary with the objective of encouraging frank and honest debate in future activities.

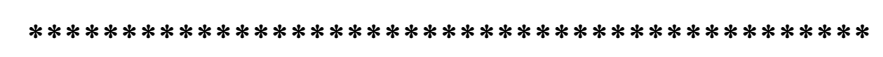


Launch of EUCERS/King's Russia Institute Study on:

"Assessing Nord Stream 2

Regulation, geopolitics and energy security in the EU, Central Eastern Europe and the UK."

EUCERS is delighted to cordially invite you the launch: Date: 11 . July 2016, 15:00-16:30 with a drinks reception afterwards.

Where: King's College London, Maughan Library, Chancery Lane, London WC2A 1LR.

In order to attend please RSVP to carola.gegenbauer@kcl.ac.uk.

\section{EUCERS ON THE ROAD}

Our team represents EUCERS at various conferences and events all over the world. This section gives a regular update and overview of conferences and interview contributions by EUCERS Director Professor Dr Friedbert Pflüger, Research Director Dr Frank Umbach and Associate Director Dr Adnan Vatansever.

\begin{tabular}{|c|c|}
\hline $\begin{array}{l}27.06 .2016 \\
\text { Stolpe, } \\
\text { Germany }\end{array}$ & $\begin{array}{l}\text { Friedbert gave a global overview of gas } \\
\text { and energy strategies at a meeting hosted } \\
\text { by the Institute for Climate Protection, } \\
\text { Energy and Mobility (IKEM). }\end{array}$ \\
\hline
\end{tabular}

23.06.2016 Frank gave a presentation and participated Krefeld, in a panel discussion "Energy Policy in Germany Europe: Interests and Interaction", at the "Young Leaders for Europe 2016", organized by the Bertelsmann Stiftung and Heinz Nixdorf Stiftung

23.06.2016 Friedbert was chair to the Walther Leisler

Berlin, Kiep Symposium and also moderated a

Germany session on Germany ${ }^{1}$ s policy towards Russia.

17.06.2016 Frank gave a presentation "Stand und Bernried, Perspektiven der Energiekooperation Germany zwischen EU und Zentralasien” („Present Situation and Perspectives of the Energy Cooperation between the EU and Central Asia“) at the energy expert seminar "Aktuelle Herausforderungen der Energieund Klimapolitik " ("Present Challenges of the Energy and Climate-Policies") of the Hanns-Seidel-Foundation's Akademie für
16.06.2016 Frank gave a presentation "Die Rolle

Bernried, Chinas: Kohle- und Klimapolitik” („The

Germany Role of China: Coal and Climate

Policies") at the energy expert seminar

"Aktuelle Herausforderungen der Energieund Klimapolitik " ("Present Challenges of the Energy and Climate-Policies") of the Hanns-Seidel-Foundation's Akademie für Politik und Zeitgeschehen.

15.06.2016 The BVEG (Association of Oil and Gas

Hannover, Producers in Germany) organised a

Germany conference on the German Energiewende and consequences of oil and gas supply. Friedbert gave a presentation on

"Geopolitical aspects of Germany's oil and gas supply".

09.06.2016 Frank gave a presentation "Critical Energy Brussels, Infrastructure Protection and

Belgium Comprehensive Emer-gency

Management", at the final conference of the "European Cooperation Network on Critical Infrastructure Protection (EUCONCIP)".

08.06.2016 Frank gave a presentation "Vulnerabilities Warsaw, of Existing European Energy Systems to

Poland Threats" at the joint conference of the Polish government and NATO-Energy Security Centre of Excellence (ENSEC)Conference : "NATO's Role in European Security - The Maritime Dimension".

07.06.2016 Friedbert moderated the Atlantik Brücke Berlin, e.V. lunch time discussion on "European Germany Energy Security - Between US LNG and Russian Gas".

02.06.2016 Friedbert spoke at a panel at the FAZ

Berlin, Energy Security Summit 2016 -

Germany Innovations for a diverse energy supply on "New technologies and business opportunities for a diverse energy supply".

$\begin{array}{ll}\text { 01.06.2016 } & \text { Frank gave a presentation and participated } \\ \text { Kuala } & \text { in the panel-discussion “Energy Prices, } \\ \text { Lumpur, } & \text { Climate Change and Geopolitics: What } \\ \text { Malaysia } & \text { Next?”, at the Asia-Pacific Roundtable - } \\ & \text { APR @ 30, Plenary 4: 'Cooperation and } \\ & \text { Contestation in a Changing Regional } \\ & \text { Landscape', }\end{array}$




\section{PUBLICATIONS}

Umbach, Frank and Slawomir Raszewski "Strategic Perspectives for Bilateral Energy Cooperation between the EU and Kazakhstan. Geo-economic and Geopolitical Dimensions in Competition with Russia and China's Central Asia Policies". EUCERS Strategy Paper No. 9. EUCERS: London 2016.

Umbach, Frank "Energy Prices, Climate Change and Geopolitics: What Next?" (Background-Paper) for the Asia-Pacific Roundtable - APR @ 30: 'Cooperation and Contestation in a Changing Regional Landscape', Kuala Lumpur, 9 June 2016 (http://www.isis.org.my/attachments/apr30/Energy_P rices,_Climate_Change_Geopolitics_-_What_Next__Dr_Frank_Umbach.pdf).

\section{SOCIAL MEDIA}

Follow @eucers on Twitter.

Like us on Facebook:

www.facebook.com/EUCERS

\section{CONTACT EUCERS}

If you have found our Newsletter interesting, wish to hear more about our activities, or, indeed, contribute with ideas or essays, please contact Carola Gegenbauer, Operations Coordinator EUCERS on carola.gegenbauer@kcl.ac.uk or call 020-7848-1912. 


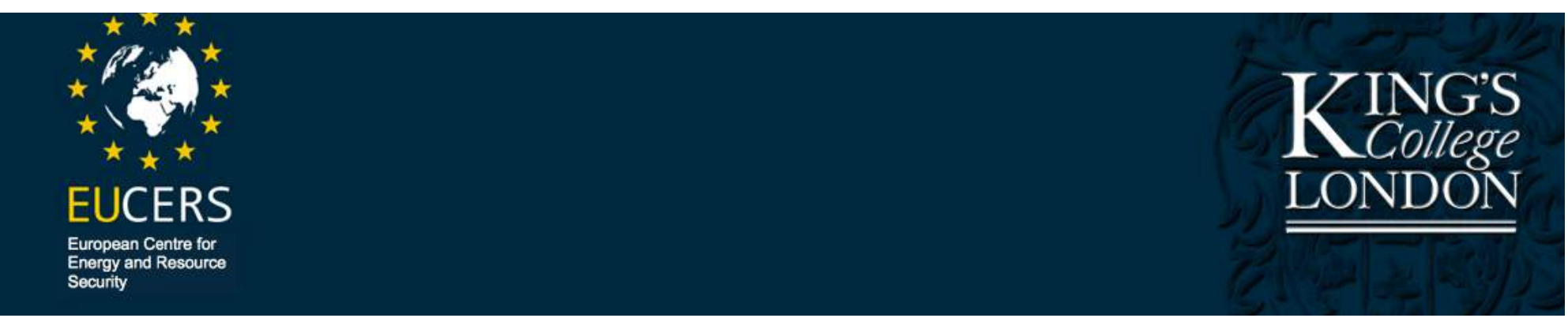

\section{EUCERS ADVISORY BOARD}

The EUCERS Advisory Board supports the activities of EUCERS King's College London. We would like to thank and present the members of the board.

Professor Theo Farrell, Chairman of the Board, Head of War Studies Department and Professor of War in the Modern World, King's College London

Marco Arcelli, Executive Vice President, Upstream Gas, Enel, Rome

Professor Dr Hüseyin Bagci, Department Chair of International Relations, Middle East Technical University Inonu Bulvari, Ankara

Andrew Bartlett, Managing Director, Bartlett Energy Advisers

\section{Volker Beckers, Chairman, Spenceram Limited}

Professor Dr Marc Oliver Bettzüge, Chair of Energy Economics, Department of Economics and Director of the Institute of Energy Economics (EWI), University of Cologne

Professor Dr Iulian Chifu, Advisor to the Romanian President for Strategic Affairs, Security and Foreign Policy and President of the Center for Conflict Prevention and Early Warning, Bucharest

Dr John Chipman, Director of the International Institute for Strategic Studies (IISS), London

\section{Professor Dr Dieter Helm, University of Oxford}

Professor Dr Karl Kaiser, Director of the Program on Transatlantic Relations of the Weatherhead Center for International Affairs, Harvard Kennedy School, Cambridge, USA
Professor Dr Karl Kaiser, Director of the Program on Transatlantic Relations of the Weatherhead Center for International Affairs, Harvard Kennedy School, Cambridge, USA

Frederick Kempe, President and CEO, Atlantic Council, Washington, D.C., USA

Ilya Kochevrin, Executive Director of Gazprom Export Ltd

Thierry de Montbrial, Founder and President of the Institute Français des Relations Internationales (IFRI), Paris

Chris Mottershead, Vice-Principal (Research \& Development), King's College London

Dr Pierre Noël, Sultan Hassanal Bolkiah Senior Fellow for Economic and Energy Security, IISS Asia

Dr Ligia Noronha, Director, Division of Technology, Industry and Economics (DTIE), United Nations Environment Programme

Janusz Reiter, Center for International Relations, Warsaw

Professor Dr Karl Rose, Senior Fellow Scenarios, World Energy Council, Vienna/London

Professor Dr Burkhard Schwenker, Chairman of the Supervisory Board, Roland Berger Strategy Consultants $\mathrm{GmbH}$, Hamburg 


\section{ACKNOWLEDGEMENTS}

We would like to thank our Partners and Supporters

\section{if acatech}

DEUTSCHE AKADEMIE DER TECHNIKWISSENSCHAFTEN

\section{Aclaria Capital}

\section{ALSTOM}

\section{At) ATLANTIC COUNCIL}

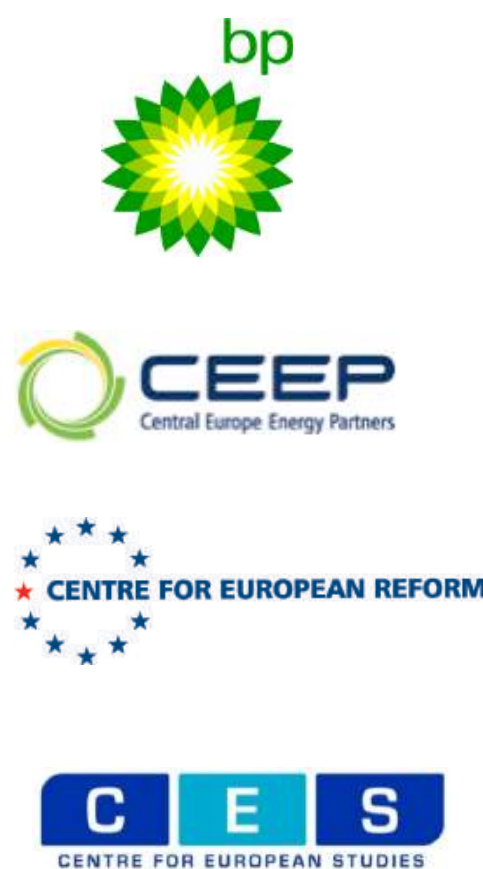

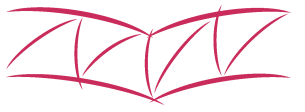

HELMUT SCHMIDT UNIVERSITÄT
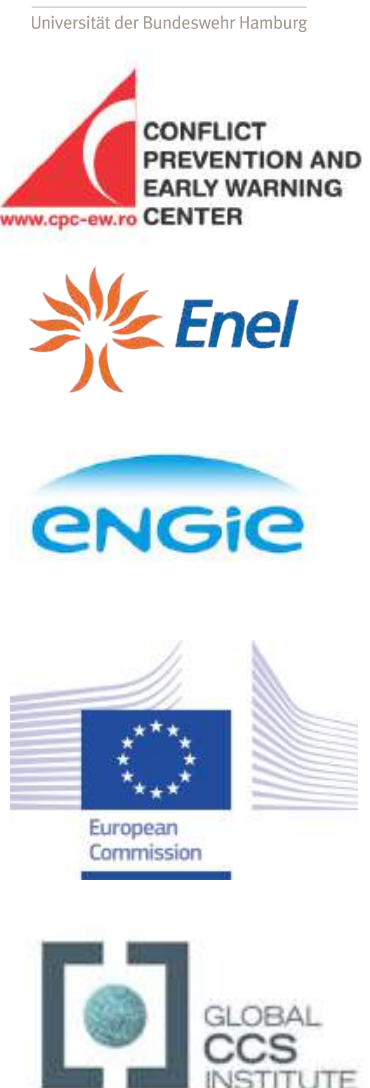

\section{RolandBerger}

Strategy Consultants

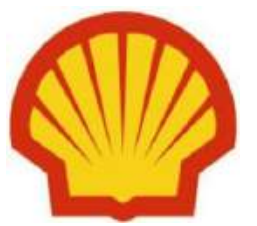

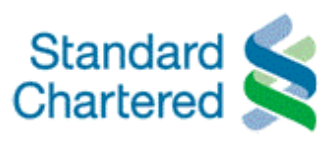

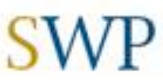

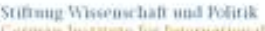
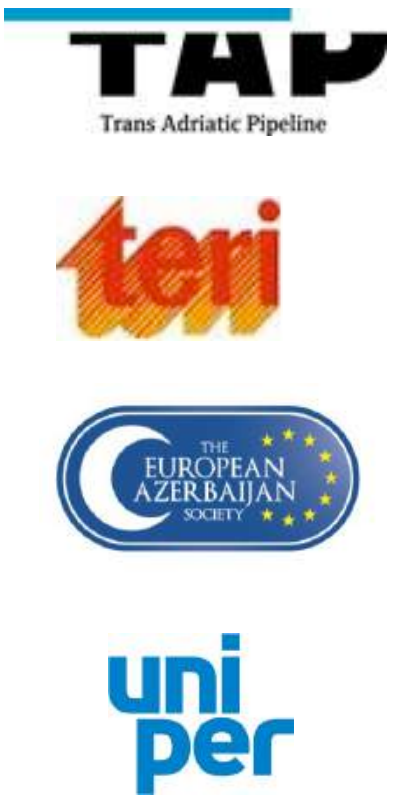

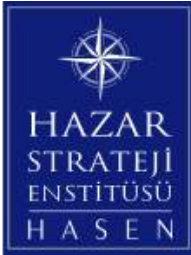

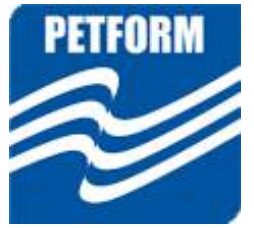

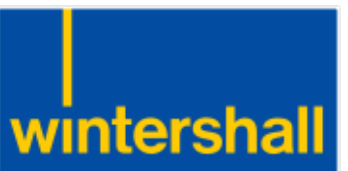

And our Media Partners:

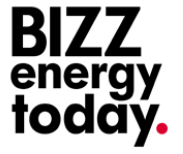

